\title{
Impact of climate change on demands for heating and cooling energy in hospitals: An in-depth case study of six islands located in the Indian Ocean region
}

\author{
Modeste Kameni Nematchoua ${ }^{\mathrm{a}, *}$, Andrianaharison Yvon ${ }^{\mathrm{b}}$, Omer Kalameu ${ }^{\mathrm{c}}$, Somayeh Asadi ${ }^{\mathrm{d}}$, \\ Ruchi Choudhary ${ }^{\mathrm{e}}$, Sigrid Reiter ${ }^{\mathrm{a}}$ \\ ${ }^{\text {a }}$ LEMA, Faculty of Applied Sciences, University of Liege, Belgium \\ ${ }^{\mathrm{b}}$ Department of Electrical Engineering, National Higher Polytechnic School of Antananarivo, Madagascar \\ ${ }^{\mathrm{c}}$ Department of Rights, Catholic University of Central Africa, Cameroon \\ ${ }^{\mathrm{d}}$ Department of Architectural Engineering, Pennsylvania University, USA \\ ${ }^{\mathrm{e}}$ Department of Architectural Engineering, University of Cambridge, UK
}

\section{A R T I C L E I N F O}

\section{Keywords:}

Climate change

Heating and cooling energy

Hospitals

Islands

Indian Ocean

\begin{abstract}
A B S T R A C T
This research was conducted in order to assess the impact that climate change has on the demands for heating and cooling energy in hospitals in six cities located in six countries in the Indian Ocean region. Three scenarios (B1, A1B, and A2) of the Intergovernmental Panel on Climate Change (IPCC) were applied in the undertaking of this work. The hourly outdoor data relating to air temperature, wind speed, relative humidity, radiation, and atmospheric pressure recorded over the last 30 years were used as inputs by Meteonorm software to enable the forecasting. The averages obtained in all the 18 models used in the IPCC report 2007 were included in the Meteonorm software and applied for assessing the future climate. The Energy-Plus software was used for assessing the thermal performance of hospitals under natural ventilation, then the energy demand during five periods (past, current, 2030, 2060, and 2090). Thermal insulation was utilized as a passive strategy for reducing cooling and heating energy consumption in the hospitals. Results showed that the use of an envelope of thermal insulation in hospitals was one of the solutions that allowed a reduction in the energy consumption for cooling and heating while increasing the thermal comfort within the hospital. Moreover, by 2090, the ventilation system was recommended in all these hospitals for improving the quality of indoor air, since the heat rate was very high. In the cases of the six islands in the Indian Ocean, each of them represented by one city, the annual energy demand for cooling will increase between 17.1 and $25.4 \%$ by $2030 ; 34.6$ and $50.2 \%$ by 2060 ; and 60.8 and $95.1 \%$ by 2090 . With the use of passive design as a strategy, the annual mean thermal performance of hospitals is predicted to increase to $184 \%$ by 2060 , while $40 \%$ of the cost of cooling energy will be saved. Despite this, the outdoor climate will be $5 \%$ harsher in Victoria than in other cities by the year 2090 .
\end{abstract}

\section{Introduction}

Taking into account all the changes that are regularly observed in our environment, and the multiplication of natural disasters occurring around the world (floods, droughts, famines, multiplication of diseases, cyclones, etc.), how do some people seem to ignore the impacts that climate change has on our environment? Nowadays, it can be observed that the world is taking note of these calamities, but in spite of that, the impact on nature remains unchanged. Indeed, the violent disasters suffered around the world in recent years had already been predicted several years earlier by climate change specialists and members of
IPCC. Today, despite the efforts of the international community, all the clauses and resolutions adopted after several summits and conferences related to this phenomenon are not always given due weightage. Human degradation of nature remains very high. Firstly, the majority of developed countries continue to destroy the environment through new technologies, yet refuse to pay compensatory taxes to the international community. Secondly, it is seen that the developing countries, or poor countries, also continue to relentlessly exploit their natural resources, which previously served to protect the environment. At this rate of degradation, the planet Earth runs the risk of becoming uninhabited in the next century, according to the current climatic variations and the

\footnotetext{
* Corresponding author.

E-mail address: kameni.modeste@yahoo.fr (M.K. Nematchoua).
} 


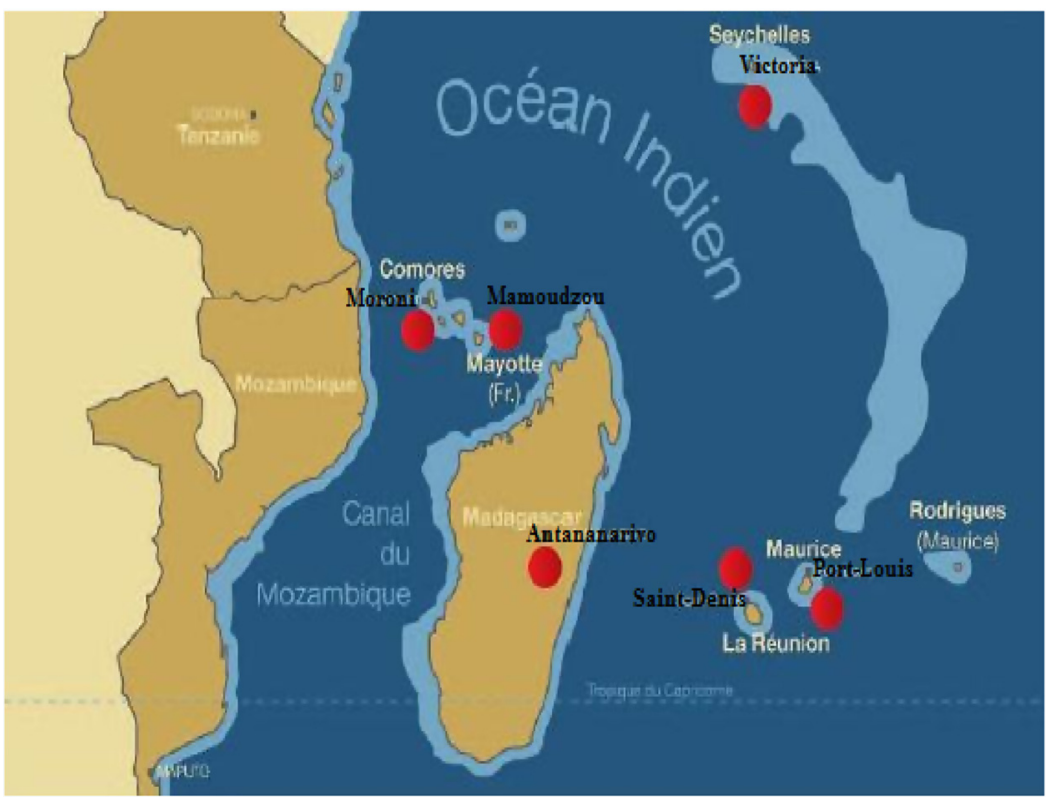

Fig. 1. Map of Six islands in India Ocean with location of six studied cities.

degree of warming that is constantly on the rise. According to the new IPCC report (Meteorological Office, 2017), during this current decade, high air temperatures were observed in some global regions. For example, throughout the year 2015, the degree of heat recorded was so high that 2015 was considered to be the warmest year of this decade. According to some researchers (Chan, 2011; Levy et al., 2004; Radhi, 2009; Rosenthal, Gruenspecht, \& Moran, 1995), it is predicted that the average air temperature during the period 2081-2100 is expected to be $0.3-4.8^{\circ} \mathrm{C}$ higher than that during the $1986-2005$ period (IPCC, 2013). The main cause of the rising global temperature is the build-up of green house gas emissions, such as carbon dioxide, methane, etc. (IPCC, 2013). The increase in the outside climate is above all a natural phenomenon. Nevertheless, the global warming observed in recent years is a consequence of the action of human beings on nature (Nematchoua, Tchinda, Roshan, Ricciardi, \& Nasrabadi, 2015a). According to IPCC, the Indian Ocean region is one of the most vulnerable regions in the world when considering the high impacts of climate change. During this past decade, each one of the countries studied was ravaged by at least three cyclones each year, which significantly affects the outside climate. Only for the year 2018, the expectation is up to 26 cyclones in this region (Saincon Cyclonique, 2017). According to A2 scenario, this study showed that the air temperature will register an increase of $3.1^{\circ} \mathrm{C}$ in this region. The energy demand in buildings depends on the fluctuations in the outdoor climate. It was seen that in the next decade the increase in air temperature increased the demand for cooling energy (Nakicenovic \& Swart, 2000; Olonscheck, Holsten, \& Kropp, 2011). In the tropical Indian Ocean climate, the cold hours of discomfort tend to diminish, while the heat hours of discomfort increase considerably. The prime role of a building is to ensure the health of its inhabitants (Nematchoua, Tchinda, Orosa, \& Andreasi, 2015b). Energy efficiency in a building is very important for reducing energy consumption. The study of impacts of climate change on cooling and heating energy is not new. This subject has already been studied by several researchers; nevertheless, the results greatly depend on the kind of building, and the climate zone. Invidiata and Ghisi (2016) showed that the use of passive design strategies in a building can result in a reduction of up to $50 \%$ of demand for cooling energy. The research of Buontempo et al. (2015) showed that climate change has a significant effect on energy demand in buildings. Hernandez Neto and Fiorelli (2000) showed that EnergyPlus software was one of the best computer simulation programs allowing to assess the thermal performance of a building. The results found by Wang and Chen (2014) showed that in the USA (San Diego), by 2080 , it will be very difficult to moderate indoor air with a passive design strategy due to very high warming levels. Asimakopoulosa et al. (2012) found that by 2100 , cooling energy demands will increase by $248 \%$ in residences in Greece. In Al-Ain City, Radhi (2009) showed that in the next decade the air temperature will increase $5.9^{\circ} \mathrm{C}$. This produce the increase of cooling energy of $23.5 \%$ compared to last decade. In Mexico, Oropeza-Perez and Østergaard (2014) found that in some warm climates in this country, thermal comfort was optimal in natural ventilation, resulting in low energy demand. In Australia, the researches of Guan (Wang, Chen, \& Ren, 2010) in some commercial buildings showed that by 2070 , the cooling energy will increase between 28 and 59\%. In the literature, in commercial and residential buildings in Switzerland, Frank (2005) found that by 2100 , the demand for cooling energy will increase from 223 to $1050 \%$, while the demand for heating energy is expected to decrease between 36 and 58\%. During the same year, in the same kind of building, Wan, Li, Pan, and Lam (2012) found an increase of cooling energy demand from 11 to $20 \%$ in China and Dodoo, Gustavsson, and Bonakdar (2014) found between 33 and 49\% in Sweden. This research is original and presented several novelties, indeed, the choice in selecting to carry out this study in several countries of the Indian Ocean was not random. Indeed, this whole region suffers every year from significant damage related to the effects of climate change. The geographical positions of these countries can testify to the degree of vulnerability of this region to global warming. Each city studied in each country was considered as one of the most vulnerable cities to face the effects of outside climate in this region. No studies have been done as yet, to evaluate the heating and cooling energy demands, distributed in all the six countries of the Indian Ocean, and covering several climate zones. In the literature, there are several works which study the cooling and heating energy demands in houses, restaurants, hotels, etc., but very little in-depth study has been conducted in the case of hospitals, especially using several IPCC scenarios for forecasting of the outside climate. The results obtained in every research varied according to climate and studied place. The impact of climate change on energy demand has not yet been studied in this region in the past. This research will provide a database in this area. Hospitals are public places accessible to all social groups, even the poorest. Health conditions determine all human activities. The demand for energy is steadily increasing in hospitals that are spread over the Indian Ocean region over the past few years. This study assessed the 
thermal performance and energy demands in the hospitals and suggested one passive strategy for increasing the comfort hours while decreasing cooling and heating energy demands.

\section{Objective}

The purpose of this research is to assess the future effects that climate change has on energy demands in a standard hospital, while the same design is found in some cities of the India Ocean, but with different climates. One passive design strategy was integrated as a method allowing to improve indoor thermal comfort, and to reduce the effect of climate change on the energy consumption in the hospitals.

\section{Method}

This research is divided into five main parts, i.e. (a) assessment and forecast of climatic data in the six cities distributed in six Indian Ocean islands with three scenarios; (b) assessment of the thermal performance of hospitals in the six cities, presently and in the future; (c) assessment of the energy performance of the buildings, presently and in the next few years; (d) assessment of thermal energy performance of the hospital after using passive design strategy, presently and in the future; (e) evaluation of cooling and heating annual energy saving cost, currently and in the next few years.

\subsection{Studied cities}

The Indian Ocean extends over an area of $75,000,000 \mathrm{~km}^{2}$, which is nearly $20 \%$ of the globe. This ocean is known for its climatic diversity with several different types of seasons (dry season, rainy season, winter and summer, etc.). It consists of several beautiful islands such as Comoros, Seychelles, Mauritius, Reunion, Madagascar, and Mayotte islands. These countries of the Indian Ocean region are strongly dominated by the pressure of the sea which considerably affects the outside climate.

Madagascar is located between $20^{\circ} 00 \mathrm{~S}$ and $47^{\circ} 00 \mathrm{E}$. Regarding the area of Madagascar which is estimated to be around $592,000 \mathrm{~km}^{2}$, this island is the fourth largest island in the world. It is separated from Africa by the Mozambique Channel which is about $400 \mathrm{~km}$ wide. A mountainous spine of $1200-1500 \mathrm{~m}$ runs through the island from the north to the south along its length. This geographic situation, the landform, the maritime influence, and wind conditions, aid in causing extremely varied climatic conditions encountered on the island. There are basically two seasons in Madagascar: dry, from May to October, and rainy, from November to April. Two short seasons of approximately one month duration separate these two seasons. From May to October, the climate is conditioned by an anticyclone. Its political capital is Antananarivo.

Mauritius is an island that has for its capital Port Louis, a city located in the northwest of the island. Its current population is 1.2 million. Mauritius covers an area of $1865 \mathrm{~km}^{2}$. This island is made up of several seasons: a winter season from June to September (with temperatures between $17^{\circ} \mathrm{C}$ at night and $25^{\circ} \mathrm{C}$ during the day). It is a very nice season. The heaviest rains and the highest temperatures are between January and March $\left(25-35{ }^{\circ} \mathrm{C}\right)$. During the summer, from January to April, the oppressive heat and humidity dominate, a sometimes oppressive humidity and the appearance of cyclones between January and March. From May to December, precipitation persists and increases the climate change.

Comoros is a group of three islands, with Moroni as its capital. This island is dominated by a tropical climate with two seasons (rainy season and dry season). Its total area is estimated at $2234 \mathrm{~km}^{2}$. The temperatures vary little during the year $\left(24-28^{\circ} \mathrm{C}\right)$, and rainfall is abundant (2000 $\mathrm{mm}$ per year on average). The sunshine is very important $(2600 \mathrm{~h}$ per year). During the rainy season (November to April), rainfall (monsoon) is particularly abundant between December and March 
Table 2

Climate conditions in the six cities.

\begin{tabular}{|c|c|c|c|c|c|c|c|c|}
\hline Country & City & Lat. and Long. & Alt. (m) & Period (year) & Ta $\left({ }^{\circ} \mathrm{C}\right)$ & RH (\%) & $\mathrm{Va}(\mathrm{m} / \mathrm{s})$ & $\mathrm{Gh}\left(\mathrm{W} / \mathrm{m}^{2}\right)$ \\
\hline Madagascar- island & Antananarivo & $18^{\circ} 54^{\prime} \mathrm{S}-47^{\circ} 32^{\prime} \mathrm{E}$ & 1274 & 1961-2009 & $14-22$ & $67-82$ & $0-4$ & $166-264$ \\
\hline Seychelles-island & Victoria & $04^{\circ} 37^{\prime} \mathrm{S}-55^{\circ} 27^{\prime} \mathrm{E}$ & 60 & 1961-2009 & $25-29$ & $74-86$ & $1-6$ & $186-238$ \\
\hline Comores-island & Moroni & $11^{\circ} 42^{\prime} \mathrm{S}-43^{\circ} 15^{\prime} \mathrm{E}$ & 27 & 1961-2009 & $23-30$ & $60-78$ & $1-4$ & $196-270$ \\
\hline Mayotte-island & Mamoudzou & $12^{\circ} 46^{\prime} \mathrm{S}-45^{\circ} 13^{\prime} \mathrm{E}$ & 23 & 1961-2009 & $24-30$ & $58-76$ & $1-4$ & $205-268$ \\
\hline Maurice-island & Port-Louis & $20^{\circ} 09^{\prime} \mathrm{S}-57^{\circ} 29^{\prime} \mathrm{E}$ & 03 & 1961-2009 & $21-28$ & $69-82$ & $2-4$ & $165-288$ \\
\hline La Reunion-island & Saint-Denis & $20^{\circ} 52^{\prime} \mathrm{S}-55^{\circ} 27 \mathrm{E}$ & 44 & 1961-2009 & $22-29$ & $66-75$ & $1-6$ & $168-275$ \\
\hline
\end{tabular}

Lat, latitude; Long, longitude; Alt, altitude; Ta, mean air temperature; RH, mean relative humidity; Va, mean wind speed; Gh, global radiation.

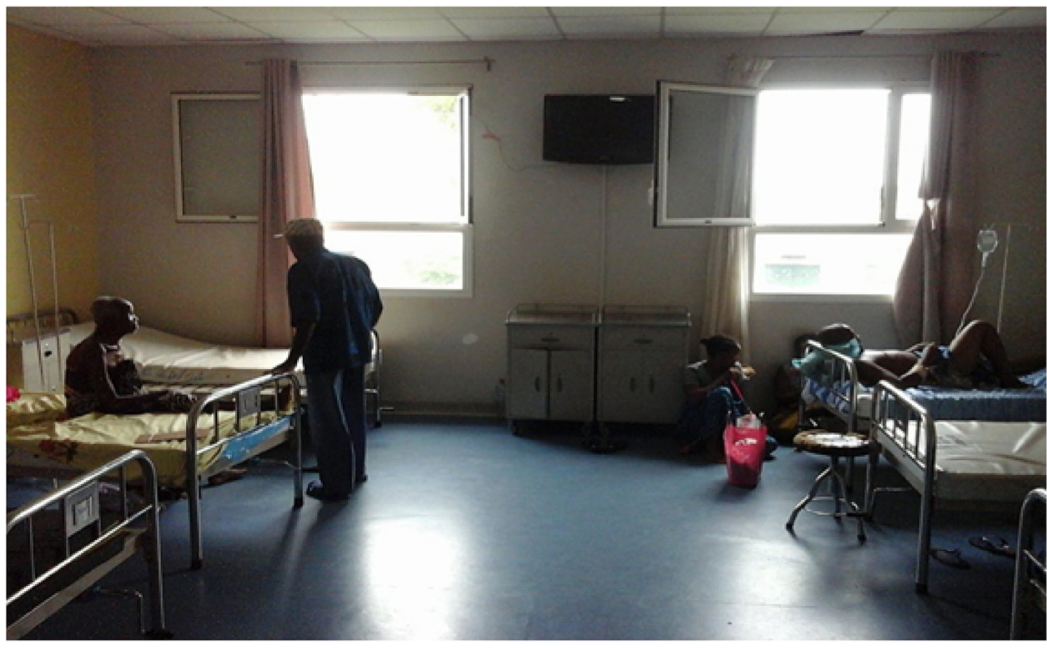

Fig. 2. Internal and external view of the hospital in Madagascar island.

Table 3

Thermal characteristics of each component of the hospital.

\begin{tabular}{llllll}
\hline $\begin{array}{l}\text { Hospital and } \\
\text { components }\end{array}$ & $\begin{array}{l}\text { Density } \\
\left(\mathrm{kg} / \mathrm{m}^{3}\right)\end{array}$ & $\begin{array}{l}\text { Thermal } \\
\text { conductivity } \\
(\mathrm{W} / \mathrm{m} \mathrm{k})\end{array}$ & $\begin{array}{l}\text { Thermal } \\
\text { capacity } \\
\left(\mathrm{kJ} / \mathrm{m}^{2} \mathrm{~K}\right)\end{array}$ & $\begin{array}{l}\text { Solar } \\
\text { absorptance } \\
(\%)\end{array}$ & $\begin{array}{l}\text { Solar } \\
\text { factor } \\
(\%)\end{array}$ \\
\hline Wall & 1150 & 0.65 & 175 & 50 & - \\
Window & 2450 & 1.16 & - & - & 80 \\
Roof & 530 & 0.14 & 20 & 50 & - \\
Floor & 600 & 0.25 & 290 & 50 & - \\
\hline
\end{tabular}

Table 4

Other implemented loads in a hospital.

\begin{tabular}{llll}
\hline Room & Load & Operating time & Requirement $\left(\mathrm{W} / \mathrm{m}^{2}\right)$ \\
\hline \multirow{2}{*}{ Sickroom } & People & Anytime & 58 \\
& Lighting & $4: 00$ PM-8:00 AM & 3 \\
\multirow{3}{*}{ Office } & Equipment & Anytime & 1.09 \\
& People & Anytime & 64 \\
& Lighting & $4: 00$ PM-8:00 AM & 6 \\
& Equipment & Anytime & 2.5 \\
\hline
\end{tabular}

(January is the wettest month). The rains are more intense on the northeastern coast and in the mountains. The average temperature is $28^{\circ} \mathrm{C}$ in December, January, February, and March. Hurricanes sometimes cause significant damage when they reach the shores of the three islands. In the dry season (May to October), temperatures are stable $\left(24^{\circ} \mathrm{C}\right)$, and precipitation is moderate.

Seychelles islands are 115 islands scattered over $338,500 \mathrm{~km}^{2}$, northeast of Madagascar, and about $1500 \mathrm{~km}$ offshore of Kenya, with Victoria as its capital. Seychelles has a tropical climate spread over two seasons (rainy season and dry season). The temperatures are constant all year long $\left(30^{\circ} \mathrm{C}\right.$ by day, $24^{\circ} \mathrm{C}$ by night), and rainfall is abundant (3000 $\mathrm{mm}$ per year). The sunshine is very important ( $7 \mathrm{~h}$ a day) and the humidity is always high. The temperature of the sea oscillates between 27 and $29^{\circ} \mathrm{C}$ all the year round. Hurricanes sometimes reach small islands south of the archipelago. During the rainy season between October and April, the temperatures slightly exceed $30^{\circ} \mathrm{C}$, and the humidity is very high (more than $80 \%$ ). The sky is regularly cloudy due to heavy rainfall. While in the dry season between May and September, temperatures are stable $\left(29^{\circ} \mathrm{C}\right)$, rainfall is low and sunshine is very important.

Mayotte Island is about $1500 \mathrm{~km}$ from Reunion, and $400 \mathrm{~km}$ from Tanzania. This country comprises two main islands with an area of $374 \mathrm{~km}^{2}$, separated by an arm of $2 \mathrm{~km}$ and about 30 small islets dotted in one of the largest coral lagoons in the world (more than $1500 \mathrm{~km}^{2}$ ) with its capital, Mamoudzou. The climate of Mayotte is of the "humid tropical" type (annual average of $25.6^{\circ} \mathrm{C}$ ) with two seasons (dry and rainy seasons). From November to April, during which the monsoon

Table 5

Thermal proprieties of expanded polystyrene.

\begin{tabular}{|c|c|c|c|c|c|c|}
\hline \multicolumn{7}{|c|}{ Thermal insulation } \\
\hline Envelope & Thickness (m) & Conductivity (W/m K) & Density $\left(\mathrm{kg} / \mathrm{m}^{3}\right)$ & Specific heat (J/kg K) & Thermal absorptance & Solar absorptance \\
\hline Wall & 0.05 & 0.04 & 24 & 1210 & 0.9 & 0.5 \\
\hline Roof & 0.05 & 0.04 & 24 & 1550 & 0.9 & 0.5 \\
\hline
\end{tabular}




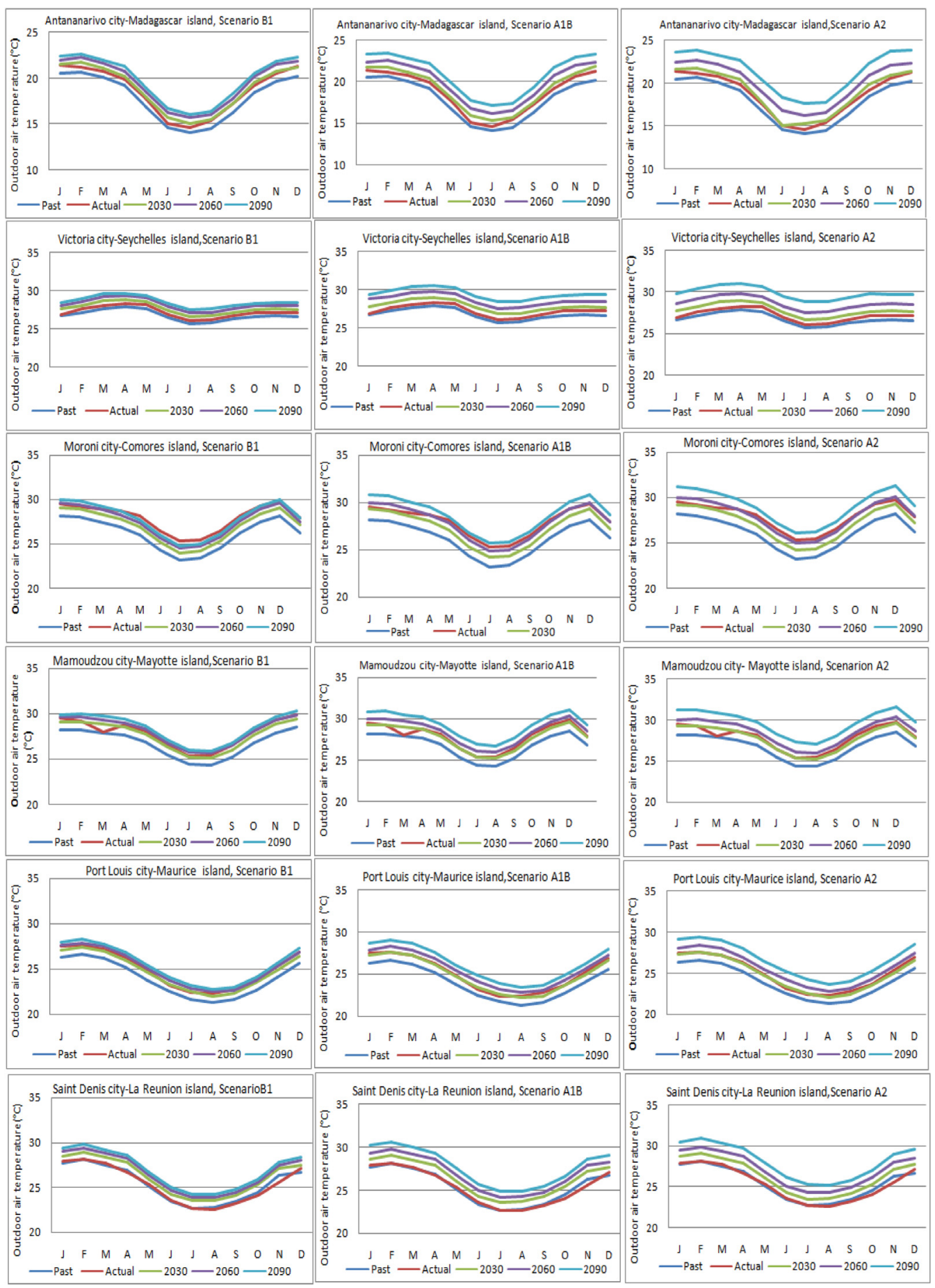

Fig. 3. Monthly mean outdoor air temperature for five different periods in six cities located in six countries with three scenarios (B1, A1B, A2).

that approaches from the north, waters the island. The temperatures are high $\left(27-30^{\circ} \mathrm{C}\right)$, and the humidity is very important. About $80 \%$ of the rainfall occurs during this period, which is a dry season, from May to October, during the austral winter. The trade winds coming from the southeast cool the atmosphere $\left(20-25^{\circ} \mathrm{C}\right)$, the humidity rate is less important, and the rain is becoming scarce.

Reunion Island is located at $700 \mathrm{~km}$ east of Madagascar, in the Mascarene Archipelago (in the Indian Ocean). The area of the island is estimated at $2512 \mathrm{~km}^{2}$, and its capital is Saint Denis. Its climate is of the humid tropical type. It varies significantly depending on the location, because of the relief of the island. There are two seasons: the "dry" season: from May to October, and the "wet" season: from November to
April. The administrative hurricane season begins around November 15 and ends around April 30. The majority of cyclones are created from the end of December to March. Fig. 1 shows the location of every studied city. Other researches were given on the Table 1.

\subsection{Climatic data}

These six researched cities are located in six different bioclimatic areas that are subjected to different climatic conditions. They are some of the cities which are the most severely affected by the effects of climate change. The data used by Meteonorm software emanates from the U.S. Department of Energy (DOE), Energy Efficiency and Renewable 


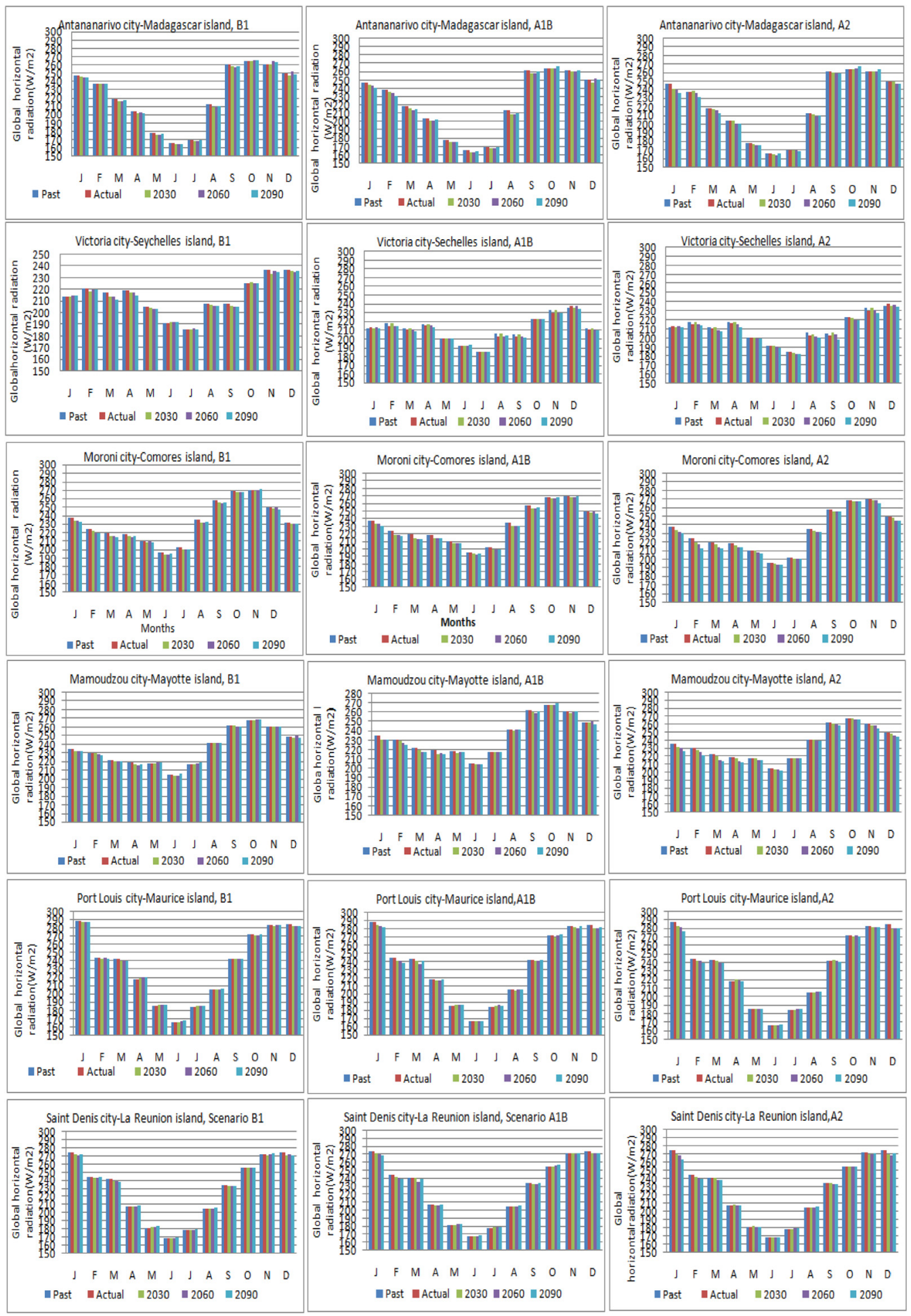

Fig. 4. Monthly mean global horizontal radiation for five different periods in six cities located in six countries with three scenarios (B1, A1B, A2).

Energy which provides weather data for more than 2100 locations throughout the world. It has five geostationary satellites updated and enhanced, especially for areas with high albedo. In this research, the data were regrouped into two categories, and each category into three separate periods. (i) Temperature, relative humidity, and wind speed: past (1961-1990), actual (2000-2009), and future (2030, 2060, 2090). (ii) Radiation: past (1981-1990), actual (1991-2010), and future (2030, 2060, 2090). The periods (2000-2009) and (1991-2010), for temperature and for radiation, respectively, were the periods most commonly used. However, at other stations, these standard periods were not the same. Some climate characteristics of these six cities are shown in Table 2.

\subsection{Simulation software}

In this research, Meteonorm and Energy-Plus software were combined. Indeed, each one of these software has a precise function.

Meteonorm was defined as a meteorological database with climatology data for solar engineering applications at every location on the globe (Remund et al., 2017). The results are stochastically generated 


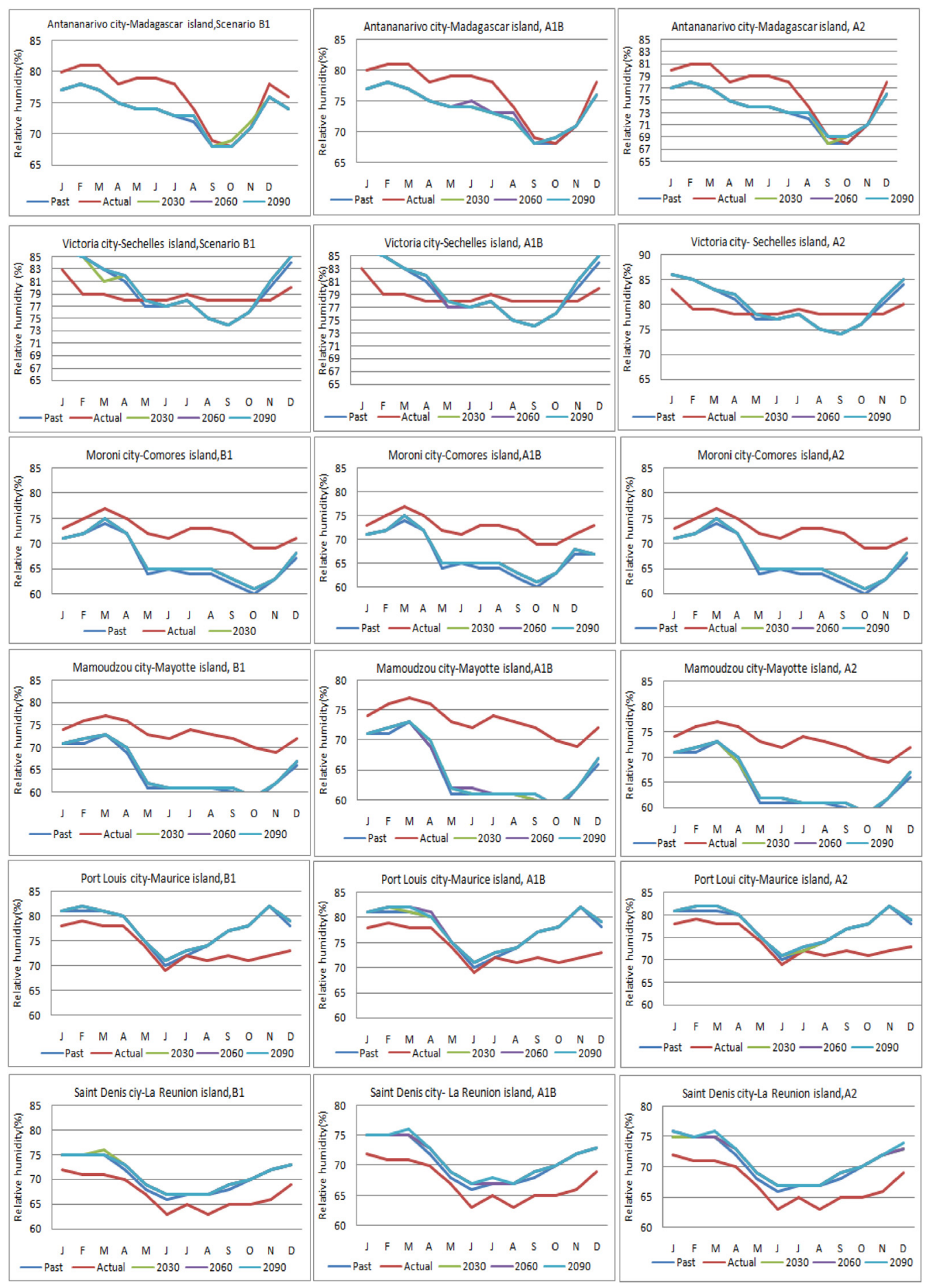

Fig. 5. Monthly mean relative humidity for five different periods in six cities located in six countries with three scenarios (B1, A1B, A2).

typical years from interpolated long-term monthly means. They represent an average year of the selected climatology time period based on the user's settings. The main practice is focalized on databases and algorithms coupled regarding a predetermined scheme. It commences with the user specifying a particular location for which meteorological data are required, and terminates with the delivery of data of the desired structure and in the required format. As explained by the authors of this software (Remund et al., 2017), measured and interpolated monthly values are of similar precision. Although measured data reflect the specific characteristics of a local site, they are always subject to measurement errors and these tend to be compensated by the interpolation process. Interpolated data should therefore be used at sites with no weather station in the vicinity (approx. $20 \mathrm{~km}$ distance) (Remund et al., 2017). Some parameters such as radiation, temperature, etc., which were evaluated through calculations as opposed to measured data, are subject to greater accuracy for reducing error propagation. It is interesting to notice that the Meteonorm software was used this last decade in several researches for forecasting outdoor climate (Affandi, Ruddin Ab Ghani, Ghan, \& Pheng, 2015; Al Tarabsheh, Etier, \& Nimrat, 2012; Ciobanu, Eftimie, \& Jaliu, 2014; Jylha et al., 2015; Nick, Mata, Sasic Kalagasidis, \& Scartezzini, 2016; Srihari Vikram \& Reddy, 2014; Stefanovic, Pavlovic, Bellos, \& Tzivanidis, 2018;

Waddicor et al., 2016; Wati, Meukam, Nematchoua, \& Rene, 2015). The most recent version, "Meteonorm 7.2 software" was used in this 

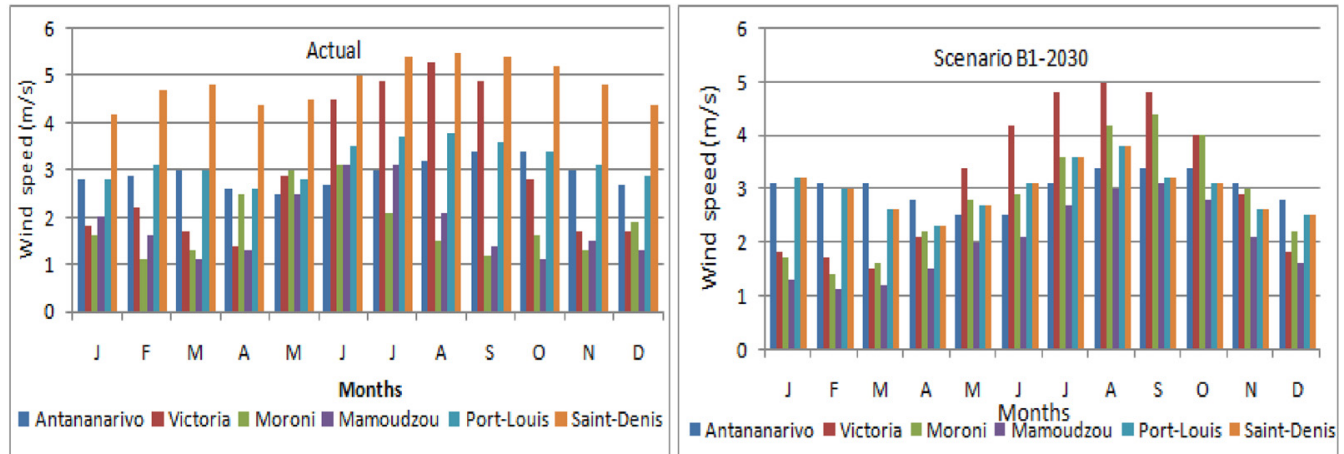

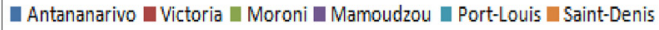

- Antananarivo = Victoria = Moroni Mamoudzou 1 Port-Louis 1 Saint-Denis
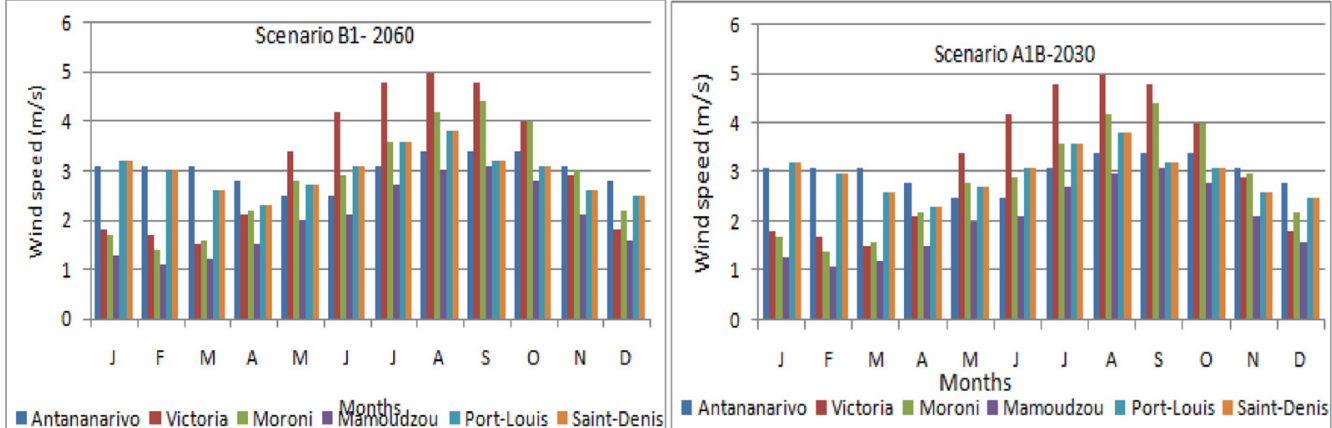

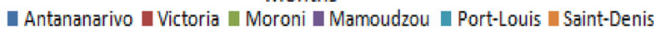

-Antananarivo Wictoria Moroni Mamolidzou Mort-Louis waint-Dents
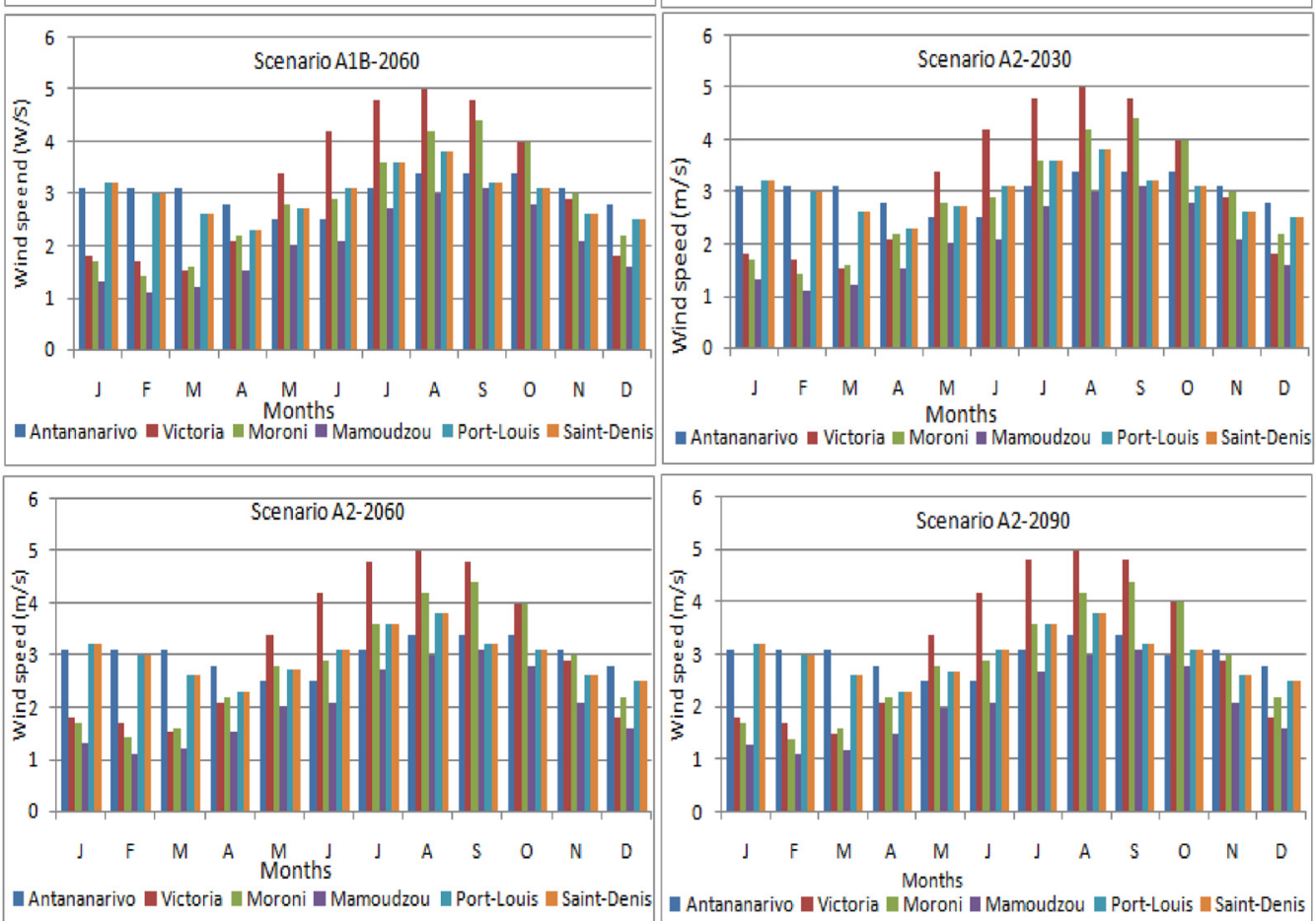

Fig. 6. Monthly mean wind speed for four different periods in six cities located in six countries with three scenarios (B1, A1B, A2).

study. It includes updated meteorological and turbidity data as well as additional features. Regarding the quality of databases, some data such as temperature and radiation were subjected to several tests. As a result, the root mean square error in interpolating monthly radiation and temperature values was found to be $7 \%$ and $1.2{ }^{\circ} \mathrm{C}$ (Remund et al., 2017). The fixed database in Meteonorm 7 contains approximately 6200 cities, 8325 weather stations, and 1200 Design Reference Year sites. After simulation, the output format could be combined at some other building simulation software such as Tryns, Energy plus, DOE, Suncode, Pleiades, Wufi passive, etc.

On the other hand, Energy Plus is one of the best software allowing to evaluate building performance and energy uses by integrating some characteristics of buildings, such as floor, window, wall, roof, etc. Further information about this software can be found in Energy Plus (2016).

\subsection{Models and scenarios}

The average of all the 18 models used in the IPCC report 2007 (IPCC, 2007) is included in Meteonorm software and is applied for forecasting. Three different scenarios, B1 (low), A1B (mid), and A2 (high) are available in this software, and used in this study. The A2 


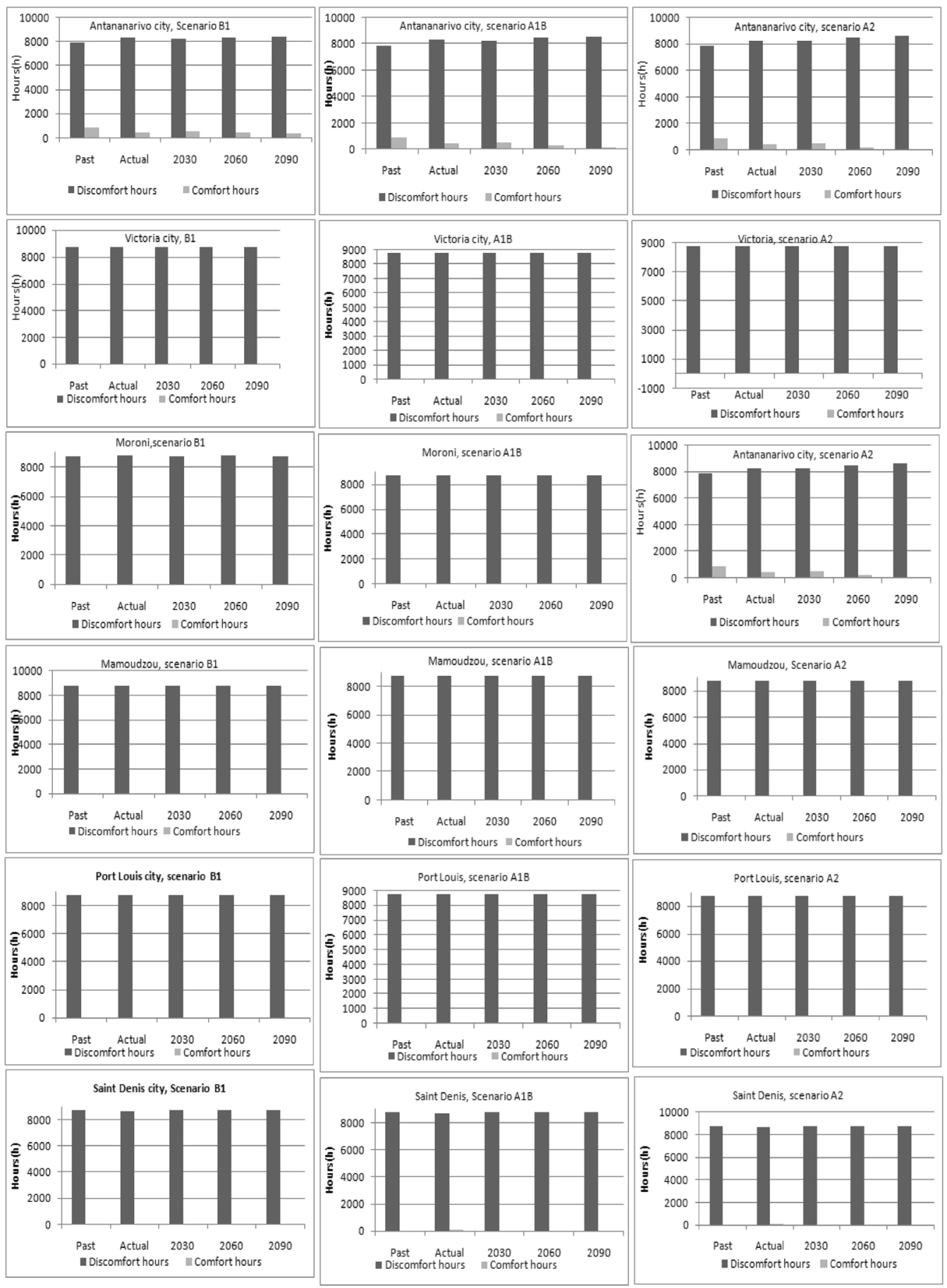

Fig. 7. Comfort hours in the hospital in the six studied cities for five different periods under natural ventilation.

scenarios are of a more divided world. The A2 family of scenarios is characterized by: a world of independently operating, self-reliant nations, continuously increasing population (Jump Up, 2000). The B1 scenarios are of a world more integrated, and more ecologically friendly. The A1B scenarios are of a more integrated world; a balanced emphasis on all energy sources (Jump Up, 2000). The anomalies of temperature, precipitation, global radiation of the periods 2011-2030, 2046-2065, and 2080-2099 were used for the calculation of future time periods.

\subsection{The hospital}

Choosing this type of building was not done at random. The hospital that was evaluated is of a standard design and is distributed in many cities of the Indian Ocean. Indeed, more than 15 such hospitals that are distributed in this region have the same design (CHU Hospital, 2013). Some studies (ASHRAE Standard, 2004; De Dear, Brager, \& Cooper, 1997; Nematchoua, Ricciardi, Reiter, Asad, \& Demers, 2017a; Nematchoua, Ricciardi, \& Buratti, 2017b; Nematchoua, Ricciardi, \& Buratti, 2018) show that the architectural design has an effect on the behavior and health of the sick. The hospitals are places par excellence where people of all social categories from different regions, with different behaviors can be found. In addition, since 1980, the surveys undertaken relating to health and the occupant's satisfaction taking into account several types of climate are encouraged to establish a new global database by ASHRAE 189.12009 and ISO standards. This 


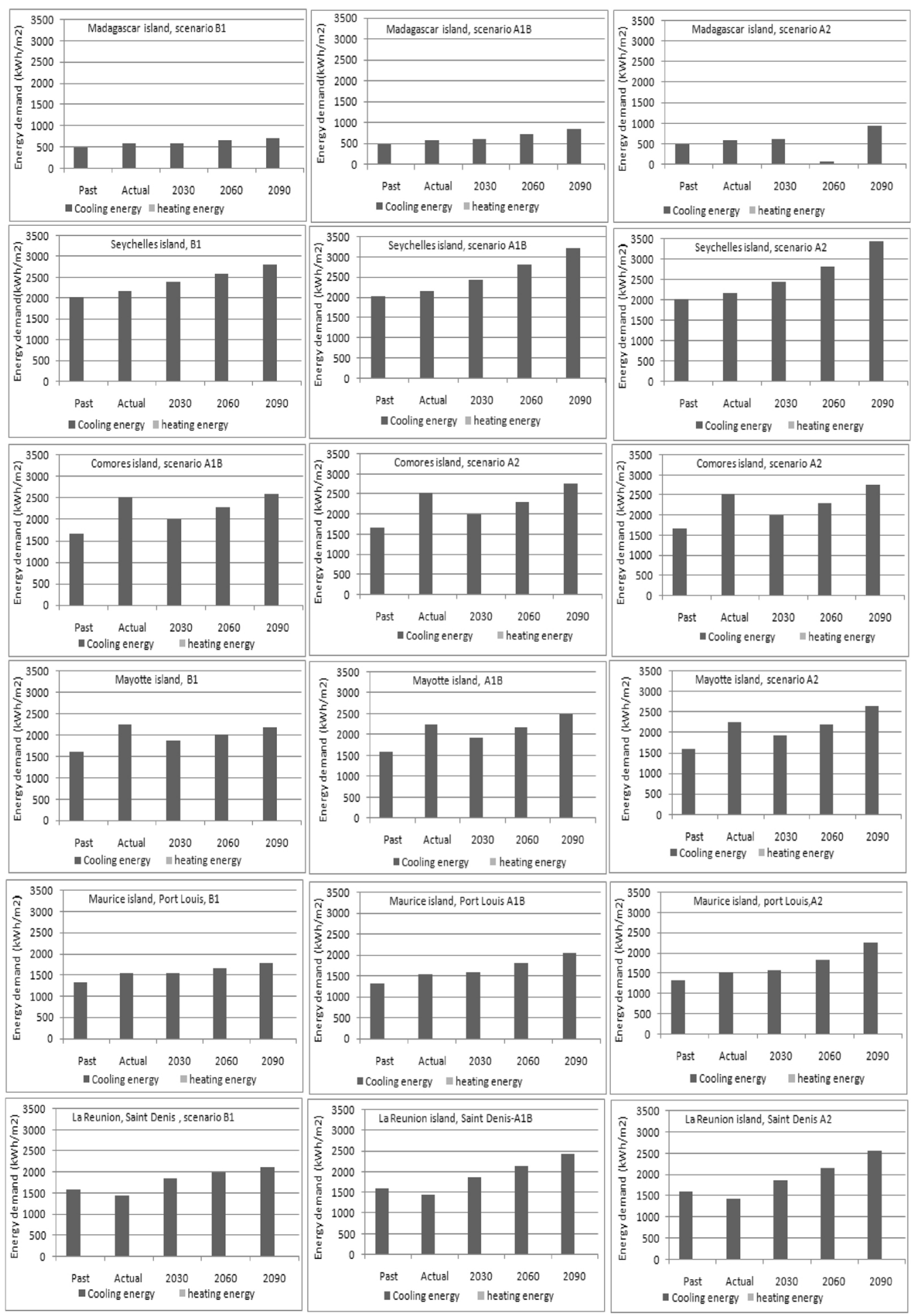

Fig. 8. Cooling and heating energy demand of the hospital in the six cities for five different periods under air-conditioned.

building was analyzed in a single orientation (main façade facing northwards).

In the hospital, only three blocks were permitted to be studied (Maternity, Pediatry, and Surgery or Emergency Room). All these three departments were almost similar (having the same design, same equipment and activity of occupant), excepting the number of sickrooms, which varied according to the number of beds and other requirements. Each block at the hospital had eight similar sick rooms, in which there were two rooms that were equipped with six beds per room, four rooms (four beds/room), and two rooms (two beds per room); and eight similar offices reserved for a doctor and trainee, which was separated from the sick room by a corridor. In each sick room, in the office, the ceiling height was $2.8 \mathrm{~m}$. The total floor plan area per block was $693 \mathrm{~m}^{2}$ (Fig. 2). The walls were made of hollow concrete blocks $14.0 \mathrm{~cm}$ thick, and a layer of mortar $2.1 \mathrm{~cm}$ thick on each side. There were two windows per room, which were composed of one single glass pane $3.5 \mathrm{~cm}$ thick, and had a white curtain. The roof was made of white plywood $0.8 \mathrm{~cm}$ thick. The floor area was made of ceramic tiles $0.95 \mathrm{~cm}$ thick.

Table 3 shows some thermal characteristics of the envelope of the 
Table 6

Confrontation between cooling energy demand in the six cities according to three scenarios.

\begin{tabular}{|c|c|c|c|c|c|c|c|c|c|c|c|c|}
\hline \multirow{2}{*}{$\begin{array}{l}\text { City } \\
\text { Scenario }\end{array}$} & \multicolumn{2}{|c|}{ Antananarivo } & \multicolumn{2}{|l|}{ Victoria } & \multicolumn{2}{|l|}{ Moroni } & \multicolumn{2}{|c|}{ Mamoudzou } & \multicolumn{2}{|c|}{ Port Louis } & \multicolumn{2}{|c|}{ Saint Denis } \\
\hline & Energy & Frequency & Energy & Frequency & Energy & Frequency & Energy & Frequency & Energy & Frequency & Energy & Frequency \\
\hline \multicolumn{13}{|l|}{ B1 } \\
\hline 2090 & 708.0 & 22.0 & 2812.8 & 30.1 & 2250.7 & - & 2181.1 & - & 1790.7 & 17.0 & 2121.7 & 47.5 \\
\hline \multicolumn{13}{|l|}{ A1B } \\
\hline 2090 & 845.0 & 66.3 & 3219.4 & 49.0 & 2584.1 & 2.5 & 2482.5 & 11.0 & 2051.3 & 34.0 & 2419.9 & 68.2 \\
\hline \multicolumn{13}{|l|}{ A2 } \\
\hline 2090 & 934.7 & 84.0 & 3447.7 & 61.0 & 2757.0 & 9.4 & 2465.1 & 10.0 & 2257.7 & 47.3 & 2556.5 & 77.7 \\
\hline
\end{tabular}

Energy $\left(\mathrm{kWh} / \mathrm{m}^{2}\right)$, frequency $(\%)$.

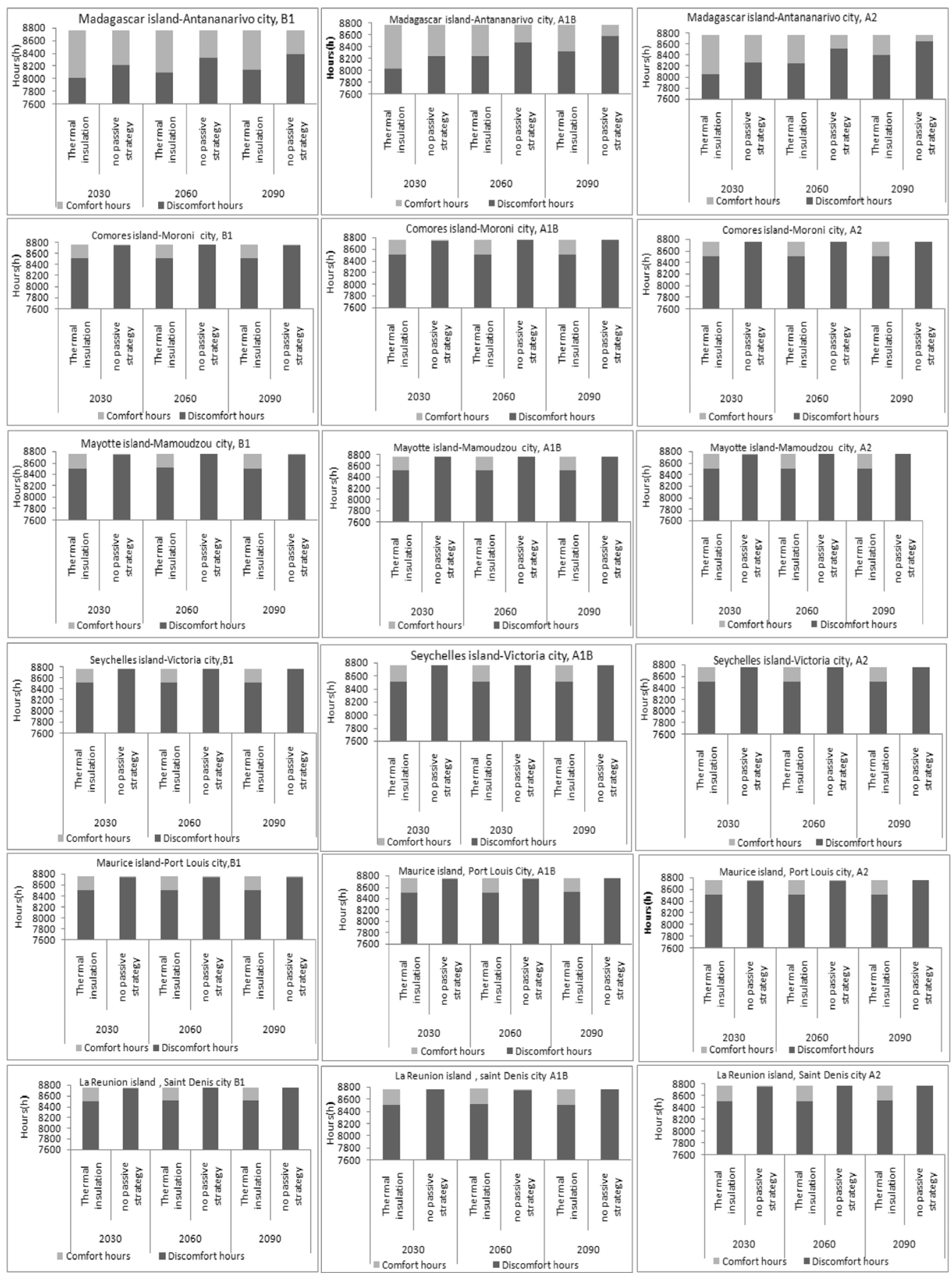

Fig. 9. Annual comfort hours in the hospital with passive design strategies in six cities located in six islands under natural ventilation. 


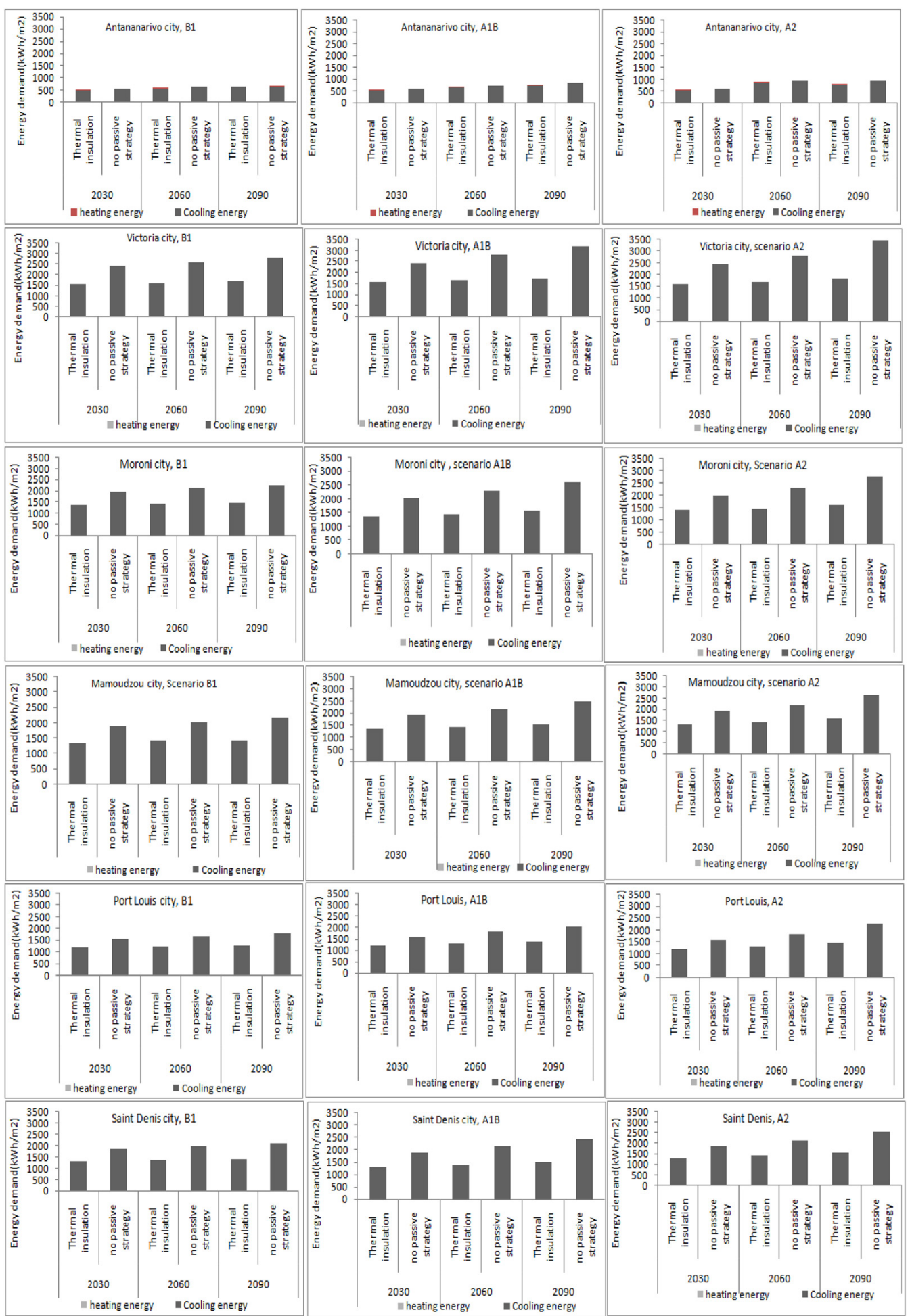

Fig. 10. Annual energy demand of the hospital with passive design strategies in six studied cities under air-conditioned using three scenarios (B1, A1B, B2).

building.

Solar factor: represents the fraction of total incident energy passing through a glazed area of a habitat compared to the energy incident on it. The elements considered during the calculation are the "Direct Solar Energy" transmittance and the indirect values of heat transfer values.

\subsection{Simulation with Energy-Plus software}

The most current version (8.8) of Energy-plus was used to assess the thermal performance under natural ventilation and with passive design, taking into account the energy demands in the hospital for the three periods. The hospital was assessed considering six people per sick room and one per office. Some details on other parameters and thermal load are shown in Table 4. The activities of people in different buildings were evaluated according to ASHRAE55 (Nematchoua, Ricciardi, \& Reiter, 2017c).

The thermal performance and energy demands were evaluated only in the sick rooms and offices (hospital). All the rooms were assessed in 


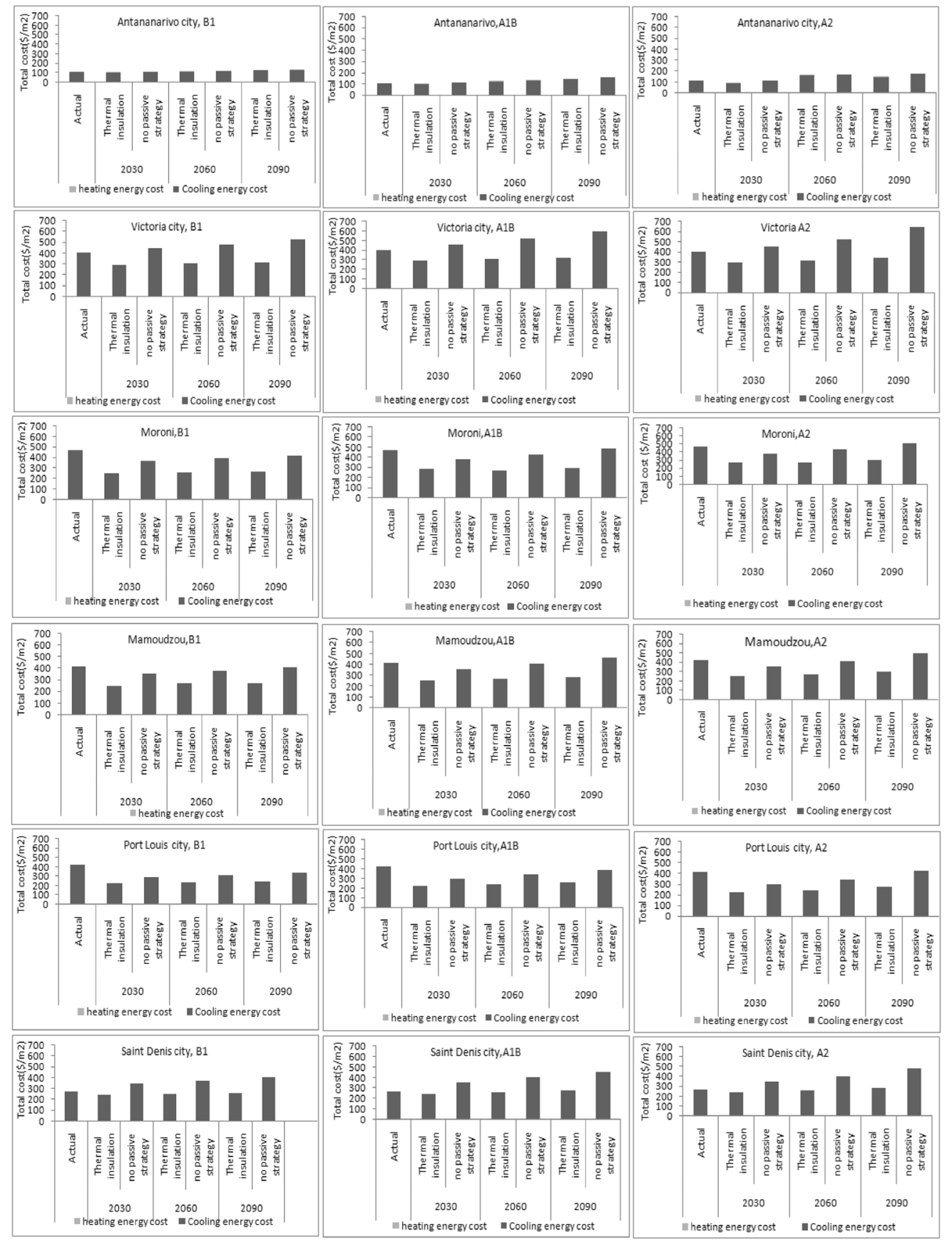

Fig. 11. Annual cooling and heating energy cost of the hospital with passive design strategies in six studied cities under three scenarios.

natural ventilation and air conditioning. According to previous researches carried out in the Indian Ocean region (Nematchoua et al., 2017a, 2017b, 2018), in natural ventilation, the operative temperatures were fixed to be around $23.9^{\circ} \mathrm{C}$ in a hospital. In all the buildings, the artificial conditioning system was adjusted according to the activities of people in the environment. Regarding this study (Nematchoua et al., 2017b), fixing the zone of thermal satisfaction in the region, for obtaining the energy consumption for air conditioning, the heating set point temperature was fixed at $18{ }^{\circ} \mathrm{C}$, and cooling set point at $24^{\circ} \mathrm{C}$.

\subsection{Adaptive thermal comfort}

In natural ventilation, with Energy-Plus software, it was possible to evaluate the number of hours corresponding to thermal comfort in the hospital. According to the literature review, it is possible to estimate the comfort temperature when more than $80 \%$ of occupants find the environment comfortable (De Dear et al., 1997). The comfort temperature varied from 22.9 to $27.2^{\circ} \mathrm{C}$ in the hospital (Nematchoua et al., 2017b, 2018). The mean time number in which the buildings was thermally comfortable was assessed under the basis of the following equation:

$t_{\mathrm{comfh}}=\sum\left(t_{\mathrm{c} 1}+t_{\mathrm{c} 2}\right) / 2$ in hospital

With all the sick rooms being similar, and the offices almost similar, where $t_{\text {comfh }}$ is the mean number of hours per year of thermal comfort in the hospital, $t_{\mathrm{c} 1}$ is the total number of hours of thermal comfort in one sick room by year, and $t_{\mathrm{c} 2}$ is total number of hours of thermal comfort in one office by year. The analysis was carried out on three periods (past, present, and future), in the six capitals of the six islands that were studied. 
Table 7

Thermal performance and cooling energy cost with implementation of thermal insulation.

\begin{tabular}{|c|c|c|c|c|c|c|c|c|c|c|c|c|}
\hline \multirow{2}{*}{$\begin{array}{l}\text { City } \\
\text { Year }\end{array}$} & \multicolumn{2}{|c|}{ Antananarivo } & \multicolumn{2}{|c|}{ Victoria } & \multicolumn{2}{|l|}{ Moroni } & \multicolumn{2}{|c|}{ Mamoudzou } & \multicolumn{2}{|c|}{ Port Louis } & \multicolumn{2}{|c|}{ Saint Denis } \\
\hline & Actual & 2090 & Actual & 2090 & Actual & 2090 & Actual & 2090 & Actual & 2090 & Actual & 2090 \\
\hline \multicolumn{13}{|l|}{ ScenarioB1 } \\
\hline No passive strategy & 463 & 382 & 100 & 0 & 127 & 4 & 118 & 02 & 116 & 06 & 100 & 0 \\
\hline $\begin{array}{l}\text { Thermal insulation } \\
\text { Total energy demand }\end{array}$ & - & 614 & - & 250 & - & 257 & - & 254 & - & 254 & - & 252 \\
\hline No passive strategy & 580.1 & 708.0 & 2161 & 2813 & 2520 & 2251 & 2240 & 2181 & 1532 & 1791 & 1439 & 2122 \\
\hline $\begin{array}{l}\text { Thermal insulation } \\
\text { Total energy cost }\end{array}$ & - & 652. 6 & - & 1671 & - & 1445 & - & 1437 & - & 1284 & - & 1386 \\
\hline No passive strategy & 108.2 & 132.1 & 404 & 527 & 471 & 421 & 419 & 408 & 419 & 335 & 270 & 400 \\
\hline $\begin{array}{l}\text { Thermal insulation } \\
\text { ScenarioA1B } \\
\text { Thermal comfort hour }\end{array}$ & - & 121.7 & - & 313 & - & 270 & - & 270 & - & 240 & - & 260 \\
\hline No passive strategy & 463 & 186 & 100 & 0 & 118 & 0 & 118 & 0 & 116 & 0 & 100 & 0 \\
\hline \multicolumn{13}{|l|}{ Total energy demand } \\
\hline No passive strategy & 580.1 & 846.1 & 2161 & 3220 & 2519 & 2584 & 2240 & 2483 & 1535 & 2051 & 1439 & 2420 \\
\hline $\begin{array}{l}\text { Thermal insulation } \\
\text { Total energy cost }\end{array}$ & - & 759.1 & - & 1736 & - & 1556 & - & 1537 & - & 1378 & - & 1487 \\
\hline No passive strategy & 108.3 & 158.2 & 403 & 602 & 471 & 483 & 417 & 464 & 420 & 384 & 270 & 452 \\
\hline $\begin{array}{l}\text { Thermal insulation } \\
\text { ScenarioA2 } \\
\text { Thermal comfort hour }\end{array}$ & - & 142.0 & - & 325 & - & 292 & - & 287 & - & 258 & - & 278 \\
\hline No passive strategy & 462 & 110 & 100 & 0 & 100 & 0 & 100 & 0 & 16 & 0 & 0 & 0 \\
\hline \multicolumn{13}{|l|}{ Total energy demand } \\
\hline No passive strategy & 580.1 & 934.8 & 2160 & 3448 & 2519 & 2756 & 2240 & 2645 & 1540 & 2259 & 1440 & 2557 \\
\hline \multicolumn{13}{|l|}{ Total energy cost } \\
\hline No passive strategy & 108.0 & 174. 8 & 404 & 644 & 470 & 515 & 417 & 495 & 419 & 422 & 270 & 478 \\
\hline Thermal insulation & - & 153.3 & - & 345 & - & 300 & - & 297 & - & 218 & - & 287 \\
\hline
\end{tabular}

Thermal comfort $(\mathrm{h})$, total energy cost $(\$ / \mathrm{m} 2)$, total energy demand $\left(\mathrm{kWh} / \mathrm{m}^{2}\right)$.

\subsection{Energy evaluation}

The energy consumption was assessed under air conditioning in the three blocks constituted with each one of eight sick rooms and eight offices in the hospital. Only cooling and heating energy were considered, because other energy uses due to equipment, lighting, etc. were not directly affected by the effects of climate change. The total energy use per year for cooling and heating in every building was obtained according to the following equations:

$E_{\mathrm{h}}=\sum 24\left(E_{\mathrm{hr}}+E_{\mathrm{hof}}\right) \quad$ in hospital

With $E_{\mathrm{h}}$ as the yearly energy use for heating of the hospital (kW h/ $\left.\mathrm{m}^{2}\right), E_{\mathrm{hr}}$ is the daily energy demand for heating of one sick room (kW h/ $\mathrm{m}^{2}$ ), and $E_{\text {hof }}$ is the daily energy demand for heating of one office $\left(\mathrm{kWh} / \mathrm{m}^{2}\right)$.

$E_{\mathrm{c}}=\sum 24\left(E_{\mathrm{cr}}+E_{\mathrm{cof}}\right) \quad$ in hospital

where $E_{\mathrm{c}}$ is the annual energy used for cooling of the hospital $\left(\mathrm{kW} \mathrm{h} / \mathrm{m}^{2}\right), E_{\mathrm{cr}}$ is the daily energy demand for cooling of one sick room $\left(\mathrm{kWh} / \mathrm{m}^{2}\right)$, and $E_{\text {cof }}$ is the daily energy demand for cooling of one office $\left(\mathrm{kW} \mathrm{h} / \mathrm{m}^{2}\right)$.

\subsection{Adaptation measures}

Observing the applied methods in other researches (Invidiata \& Ghisi, 2016; Nematchoua et al., 2015c, 2017c; Jylha et al., 2015; Nika et al., 2016; Waddicor et al., 2016; Wati et al., 2015), in this study, for mitigating the impacts of climate change on thermal comfort and the cooling energy demands of buildings, thermal insulation was applied as passive strategy. For this purpose, expanded polystyrene was selected and applied on the roofs and walls of hospital in the six cities with different climates, and a comparison was carried out regarding the energy behavior and the variation of comfort hours in the buildings. The passive design strategy was freely selected on EnergyPlus, and applied on three periods (past, present and future). Table 5 reveals the thermal characteristics of the insulation used.

\subsection{Annual total cost saving of heating and cooling energy demands}

The cost of energy demands was evaluated by taking the average cost per unit of energy expressed in $\mathrm{kWh}$, in each of the six cities studied. The currency used in the document is USD.

\section{Results}

\subsection{Analysis of climate data}

Figs. 3-6 show some climate data assessed in this study in the different cities during the three periods: past, present, and future (2030, 2060, and 2090). Fig. 3 shows the monthly outdoor air temperature for different periods in the six cities located in six countries with three different scenarios (B1, A1B, A2). It can be seen that the air temperature did not vary with the same standard deviation in all the countries. According to scenario B1, by 2060, the annual mean outdoor air temperature in these cities will increase by up to $1.6^{\circ} \mathrm{C}$, while regarding scenario A2, in these six cities, an average increase of air temperature between 2.5 and $3.2^{\circ} \mathrm{C}$ by 2090 was expected. It is important to note that the air temperature increase was weaker in Antananarivo than in the five other cities. In addition, Fig. 4 shows the comparison of monthly mean global horizontal radiation. In all the cities, the global radiation will slightly increase in the future. Regarding the three scenarios B1, A1B, and A2, it was seen that by 2090, the radiation will increase by up to $1.0,2.2$, and $5.2 \%$, respectively, compared to the current values.

On the other hand, Fig. 5 shows the fluctuation in the monthly mean 
relative humidity during the different seasons in the cities. The relative humidity will decrease in the next decade in Antananarivo, Victoria, Moroni, and Mamoudzou, till 2.5 and $8.2 \%$ according to scenarios B1 and A2, respectively. Moreover, it is interesting to see that by 2090, the mean relative humidity will increase $3.5 \%$ (according to scenario B1), and 3.9\% (A2), in Port Louis City and Saint Denis, respectively. Finally, Fig. 6 shows a comparison of monthly mean wind speed for four different periods. The wind speed will increase over the years in the four cities except Saint Denis and Port Louis. According to scenario A2, by 2090, the annual mean wind speed will increase $0.07 \mathrm{~m} / \mathrm{s}$ in Antananarivo, $0.2 \mathrm{~m} / \mathrm{s}$ in Victoria, $0.15 \mathrm{~m} / \mathrm{s}$ in Moroni, and $0.26 \mathrm{~m} / \mathrm{s}$ in Mamoudzou; but, it will decrease $0.19 \mathrm{~m} / \mathrm{s}$ in Port Louis and $1.8 \mathrm{~m} / \mathrm{s}$ in Saint Denis.

\subsection{Analysis of thermal performance}

The adaptive thermal comfort was adopted and the performance of the hospital was assessed in natural ventilation. Fig. 7 shows the performance of the hospital during the five periods in each city. According to scenario B1, by 2090, the indoor discomfort hours will increase by 9.7\%, 1.1\%, and 8.2\%, in Antananarivo, Port Louis, and Saint Denis, respectively. Meanwhile, according to A1B, the indoor discomfort hours will increase of $3.3,2.0$, and $8.2 \%$ in Antananarivo, Port Louis, and Saint Denis, respectively. Nevertheless, regarding A2, in natural ventilation, it was noticed that all these hospitals were totally uncomfortable during all the seasons in each city. These results justify the strong pressure of the outside climate on the thermal performance of the hospital. It is imperative to use a passive strategy to improve indoor air.

\subsection{Analysis of energy demand}

In each city, cooling and heating energy was assessed during all the seasons according to the differently used scenarios. Fig. 8 shows the energy demand in the hospital. In all these cities, cooling energy varied from 589.2 to $2432 \mathrm{~kW} \mathrm{~h} / \mathrm{m}^{2}$ by 2030 , and from 708 to $3450 \mathrm{~kW} \mathrm{~h} / \mathrm{m}^{2}$ by 2090 while heating energy was almost neglected. In all these cities, the annual cooling energy was higher than $1000 \mathrm{~kW} \mathrm{~h} / \mathrm{m}^{2}$, except in Antananarivo. It is interesting to observe that demands for cooling energy will increase in the next decade compared to the actual energy demand. Summary results of energy demands in the future compared to the recent year are shown in Table 6.

It can be seen in Table 5 that by 2090, regarding scenario B1, cooling energy will increase by $22 \%$ in Antananarivo, $30.1 \%$ in Victoria, $17 \%$ in Port Louis, and $47.5 \%$ in Saint Denis compared to the current year. On the other hand, the scenario A2 showed that cooling energy will increase by $84.0 \%$ in Antananarivo, $61.0 \%$ in Victoria City, $47.3 \%$ in Port Louis, and $77.7 \%$ in Saint Denis compared to the actual year. The same scenario showed that cooling energy will increase only $9.4 \%$ in Moroni by 2090 . These different energy growth demands can be due to global warming.

\subsection{Analysis of thermal performance of buildings after using passive design strategy}

For mitigating cooling and heating energy demands in the hospitals, expanded polystyrene was applied on the roofs and walls as passive design strategy during the five studied periods. Some results are presented in Figs. 9-11. Fig. 9 shows the annual thermal performance in the hospital with passive design strategies in six cities located in six islands under natural ventilation. In all the cities, it was observed that the comfort hours increased when we applied the polystyrene on the roofs and walls. Despite this, the heat and cool discomfort hours still remained significant. According to scenario A1B (middle), by applying the passive strategy (thermal insulation of envelope), by 2060, the thermal performance of hospitals will increase up to $85.2 \%$ in Antananarivo; 250\% in (Moroni, Mamouzou, and Victoria); and $84 \%$ in
Saint Denis. Globally, the thermal performance of hospitals was the highest (optimal) in Antananarivo and the lowest in Victoria City.

\subsection{Analysis of energy demand and cooling cost after using passive design strategy}

Fig. 10 shows the annual energy demands of the hospitals, with passive design strategies in the six studied cities under air conditioning. Similar to the results showed by Kameni et al. (Nematchoua et al., 2017a; Nematchoua et al., 2015d), it was seen that cooling energy decreased when insulation thickness was optimal and fixed to be around of $0.057 \mathrm{~m}$. By 2090, cooling energy demands will decrease up to $40 \%$ in all the cities after applying thermal insulation on the roofs and walls. The cooling energy demand was the least in Antananarivo compared to the five other cities. Fig. 11 shows the annual cooling and heating energy cost in the hospitals with passive design strategy. In all the cities, the annual energy cost will decrease with the implementation of thermal insulation of the envelope. According to scenario A2, by 2060, cooling energy costs will decrease $40.4 \%$ in Victoria, $36.3 \%$ in Moroni City, 34.7\% in Mamoudzou and Saint Denis, then 28. 8\% in Port Louis, compared to the current year. Table 7 shows a summary comparison of thermal performance in buildings, and the annual energy costs with passive strategy for six cities situated in six islands during two study periods.

Analysis of Table 6 shows that the implementation of insulation on different faces of a building is very important for improving the thermal comfort of the hospital and reduces the cooling and heating demands. Moreover, it was noticed that from 2090 the passive strategy does not improve the indoor air because the heat rate is very high. According to scenario B1, thermal insulation applied on the roofs and walls of the hospital will allow to save by 2090, 901\$(USD) in Antananarivo, 18532 in Victoria, 13077 in Moroni, 11951 in Mamoudzou, 8227\$ in Port Louis City, and $12124 \$$ in Saint Denis City.

\section{Discussions}

Indoor air should be moderate and comfortable to support the healing of patients in hospitals. Nowadays, several effects linked to climate change directly affect human health. The interpretation of the results of this study shows that in natural ventilation, patients in the studied hospitals were uncomfortable.

The application of thermal insulation on the building facades will allow to improve thermal comfort and reduce energy consumption. The thermal performance is optimal by fixing at $0.04 \mathrm{~m}$ expanded polystyrene. These results confirm the results found by Kameni et al. (Nematchoua et al., 2015c), who found in a study conducted in hot and wet tropical climates that the thickness of the insulation was set to be around $0.057 \mathrm{~m}$ for optimal habitat performance.

The external climate is increasing alarmingly. The air temperature has a significant effect on energy demand. Indeed, the average temperature is expected to increase up to 1.9 and $3.1{ }^{\circ} \mathrm{C}$ according to scenarios B1 and A2, respectively, in the next decade, in all the cities, compared to the current year. This variation is not a surprise because it was predicted by the IPCC (IPCC, 2007). The strong fluctuation of the indoor climate may be due to the geographical location of each of these countries. In all the six cities, air temperature increases the highest in Victoria City and the least in Antananarivo. The weak rise in air temperature in Antananarivo City compared to other cities can be due to altitude effect. Indeed, this city is located at an altitude of $1274 \mathrm{~m}$ (Table 1). In all the cities, the discomfort hours are over $8000 \mathrm{~h}$ per year (Fig. 7) in natural ventilation in the hospitals. This shows that the majority of sick rooms were uncomfortable. Thus, by 2090, regarding scenario A2, the demand for cooling energy was expected to be between 934.8 and $3448 \mathrm{~kW} \mathrm{~h} / \mathrm{m}^{2}$ in all the cities. Moreover, with thermal insulation in all the cities, the demands for cooling energy will decrease by up to 819.6 and $1845 \mathrm{~kW} \mathrm{~h} / \mathrm{m}^{2}$. In all the cities, the annual cooling 
energy demand will increase between 17.1 and $25.4 \%$ by $2030 ; 34.6$ and $50.2 \%$ by 2060 ; and 60.8 and $95.1 \%$ by 2090 . These results are close to those found by Yilha et al. (Jylha et al., 2015), in the Finland residential areas. It can be seen that the results of each one of these studies (Dirks et al., 2015; Huang \& Hwang, 2016; Radhi, 2009) depended on climate type and building design. As shown in Fig. 11, the passive strategy will allow to save by $2090,10 \$ / \mathrm{m}^{2}$ in Antananarivo, and $214 \$ / \mathrm{m}^{2}$ in Victoria, and an annual mean of $124.7 \$ / \mathrm{m}^{2}$ for all the cities. This cost is close to those found by Kameni et al. (Nematchoua et al., 2015c) in a wet and hot tropical climate. From 2060, with the rise in outdoor climate, the heat discomfort hours will increase, while the cold discomfort hours are expected to decrease, as shown by Invidiata and Ghisi (2016). By 2060, the thermal performance will increase up to $184 \%$ with insulation of the envelope. In fact, thermal insulation limits the transfer of heat through the walls. As in some other researches (Chan, 2011; Invidiata \& Ghisi, 2016Rosenthal et al., 1995; Wang \& Chen, 2014), other passive strategies can be used, such as: solar shading, roller shutters, and low absorptance, with the aim to improving indoor building performance while reducing demands on cooling and heating energy.

\section{Conclusion}

This research evaluated the effects of climate change on energy demands in the hospitals in six cities located in six islands in the Indian Ocean region. The average of all the 18 models used in the IPCC report 2007 is included in Meteonorm software and applied for assessing the future climate. In the next decade, as asserted IPCC in 2007, the air temperature is expected to be around 1.9 and $3.1{ }^{\circ} \mathrm{C}$, in all the cities studied, according to the scenarios B1 and A2. Thus, this variation of temperature will have a significant impact on cooling energy demands in hospitals. Global warming affected the thermal performance of the hospitals. From 2090, because the heating rate was very high, a proper ventilation system will be required in order to improve indoor air quality inside the hospitals. In the next decade, with relative humidity over $85 \%$ and air temperature under $18^{\circ} \mathrm{C}$, the environment would be totally uncomfortable. The use of thermal insulation allows to save up to $40 \%$ of cooling energy cost in the hospitals. It was found that cooling energy decreases when insulation thickness increases up to 0.04 in all the cities. It is very important to think about the future climate conditions. The results of this research should allow to some governments of Indian Ocean to adopt passive design strategies for mitigating the effects of climate change on energy consumption. The choice of adapted materials for the new climate and passive design are two different suggested strategies for reducing energy consumption in the buildings, while increasing the thermal comfort of the environment. Nevertheless, this work, such as other studies in the literature, has some limitations which will be solved in future researches:

\footnotetext{
- Alone, one city per country were analyzed. These countries have several territories with different climate conditions.

- Alone, one standard hospital was evaluated, it is important to extend this study in other places such as schools, hotels, shopping centers, household, etc.

- Alone three emission scenarios were considered, it is also important to expand this study by using other new scenarios, such an RCP 2.6, RCP 4.5, and RCP 8.5.

- Alone one passive design strategy was applied, it will interesting to extend this research by using other passive design strategies to mitigate the impacts of climate change on the energy demand, such as, low absorptance, and solar shading.
}

\section{References}

Affandi, R., Ruddin Ab Ghani, M., Ghan, C. K., \& Pheng, L. G. (2015). The impact of the solar irradiation, collector and the receiver to the receiver losses in parabolic dish system. Procedia - Social and Behavioral Sciences, 195, 2382-2390.

Al Tarabsheh, A., Etier, I., \& Nimrat, A. (2012). Energy yield of tracking PV systems in Jordan. International Journal of Photoenergy, 2012, 890183. https://doi.org/10.1155/ 2012/890183.

Amato, A., Ruth, M., Kirshen, P., \& Horwitz, J. (2005). Regional energy demand responses to climate change: Methodology and application to the Commonwealth of Massachusetts. Climatic Change, 71, 175-201.

ASHRAE Standard 55. Thermal environment conditions for human occupancy, Atlanta, GA, USA, 2004.

Asimakopoulosa, D. A., Santamourisa, M., Farroua, I., Laskari, M., Saliari, M., Zanisa, G., Giannakidis, G., Tigasb, K., Kapsomenakisc, J., Douvisc, C., Zerefosd, S. C., \& Antonakaki Giannakopoulos, T. (2012). Modelling the energy demand projection of the building sector in Greece in the 21st century. Energy and Buildings, 49, 488-498.

Berger, T., Amann, C., Formayer, H., Korjenic, A., Pospischal, B., Neururer, C., \& Smutny, R. (2014). Impacts of climate change upon cooling and heating energy demand of office buildings in Vienna, Austria. Energy and Buildings, 80, 517-530.

Buontempo, C., Mathison, C., Jones, R., Williams, K., Wang, C., \& McSweeney, C. (2015) An ensemble climate projection for Africa. Climate Dynamics, 44, 2097-2118. https:// doi.org/10.1007/s00382-014-2286-2.

Chan, A. L. S. (2011). Developing future hourly weather files for studying the impact of climate change on building energy performance in Hong Kong. Energy and Buildings, 43, 2860-2868.

Financial of construction of CHU hospital in some cities in Madagascar (2013). https:// www.google. $\mathrm{cm} /$ search?q = Projet + hopital + Manarapentra + de + Madagascar\& $\mathrm{tbm}=\mathrm{isch} \&$.

Ciobanu, D., Eftimie, E., \& Jaliu, C. (2014). The influence of measured/simulated weather data on evaluating the energy need in buildings. Energy Procedia, 8, 796-805.

De Dear, R., Brager, G., \& Cooper, D. (1997). Developing an adaptive model of thermal comfort and preference. Final Report-ASHRAE Project RP 884.

Dirks, J., Gorrisen, W., Hathaway, J., Skorski, D., Scott, M., Pulsipher, T., Huang, M., Liu, Y., \& Rice, J. (2015). Impacts of climate change on energy consumption and peak demand in buildings: A detailed regional approach. Energy, 79, 20-32.

Dodoo, A., Gustavsson, L., \& Bonakdar, F. (2014). Effects of future climate change scenarios on overheating risk and primary energy use for Swedish residential buildings. Energy Procedia, 61, 1179-1182.

EnergyPlus $^{\mathrm{TM}}$, Version 8.7, Documentation, Getting Started, U.S. Department of Energy, September 30, 2016.

Frank, T. (2005). Climate change impacts on building heating and cooling energy demand in Switzerland. Energy and Buildings, 37, 1175-1185.

Guan, L. (2009). Implication of global warming on air-conditioned office buildings in Australia. Building Research and Information, 37, 43-54.

Hernandez Neto, A., \& Fiorelli, F. A. S. (2008). Comparison between detailed model simulation and artificial neural Net work for forecasting building energy consumption. Energy and Buildings, 40, 2169-2176.

Huang, K.-T., \& Hwang, R.-L. (2016). Future trends of residential building cooling energy and passive adaptation measures to counteract climate change: The case of Taiwan. Applied Energy, 184(15), 1230-1240.

Invidiata, A., \& Ghisi, E. (2016). Impact of climate change on heating and cooling energy demand in houses in Brazil. Energy and Buildings, 130, 20-32.

IPCC (2007). Climate Change 2007: Synthesis Report. Contribution of Working Groups I, II and III to the Fourth Assessment Report of the Intergovernmental Panel on Climate ChangeCambridge, UK: Cambridge University Press.

IPCC (2013). Summary for Policy Makers. Climate: The Physical Science Basis. Contribution of Working group I to the Fifth Assessment Report of the Intergovernmental Panel on Climate Change.

Jump up, "Technical Summary", 3, Review of Past, IPCC, Emissions Scenarios, in, IPCC, SRES, 2000, p. 24.

Jylha, K., Jokisalo, J., Ruesteenoja, K., Pilli-Sihvola, K., Kalamess, T., Seitola, T., Makela, H. M., Kyvonen, R., Laapas, M., \& Drebs, A. (2015). Energy demand for the heating and cooling of residential houses in Finland in a changing climate. Energy and Buildings, 99, 104-116.

Levy, P. E., Cannell, M. G. R., \& Friend, A. D. (2004). Modelling the impact of future changes in climate, $\mathrm{CO}_{2}$ concentration and land use on natural ecosystems and the terrestrial carbon sink. Global Environmental Change, 14, 21-30.

Meteorological Office, 2017. Weather and Climate Change, 2016, http://www.metoffice gov.uk/news/releases/archive/2016/2015-global-temperature (accessed 10.06. 2017).

Nakicenovic, N., \& Swart, R. (2000). Special report on emissions scenarios. A Special Report of Working Group III of the Intergovernmental Panel on Climate ChangeCambridge, UK and New York, NY, USA: Cambridge University Press.

Nematchoua, M. K., Raminosoa, C. R. R., Mamiharijaona, R., René, T., Orosa, J. A., Elvis, W., \& Meukam, P. (2015c). Study of the economical and optimum thermal insulation thickness for buildings in a wet and hot tropical climate: Case of Cameroon. Renewable and Sustainable Energy Reviews, 50, 1192-1202.

Nematchoua, M. K., Raminosoa, C. R. R., Mamiharijaona, R., René, T., Orosa, J. A., Elvis, W., \& Meukam, P. (2015d). Study of the economical and optimum thermal insulation thickness for Buildings in a wet and hot tropical climate: Case of Cameroon. Renewable and Sustainable Energy Reviews, 50, 1192-1202.

Nematchoua, M. K., Ricciardi, P., \& Buratti, C. (2017b). Statistical analysis of indoor parameters an subjective responses of building occupants in a hot region of Indian ocean: a case of Madagascar island. Applied Energy, 208, 1562-1575.

Nematchoua, M. K., Ricciardi, P., \& Buratti, C. (2018). Adaptive approach of thermal comfort and correlation between experimental data and mathematical model in some schools and traditional buildings of Madagascar under natural ventilation. Sustainable Cities and Society. https://doi.org/10.1016/j.scs.2017.11.029.

Nematchoua, M. K., Ricciardi, P., Reiter, S., Asad, S., \& Demers, C. M. H. (2017a). 
Thermal comfort and comparison of some parameters coming from hospitals and shopping centers under natural ventilation: The case of Madagascar Island. Journal of Building Engineering, 13, 196-206.

Nematchoua, M. K., Ricciardi, P., Reiter, S., \& Yvon, A. (2017c). A comparative study on optimum insulation thickness of walls and energy savings in Equatorial and Tropical climate. International Journal of Sustainable Built Environment, 6(170-182), 11-23.

Nematchoua, M. K., Tchinda, R., Orosa, J. A., \& Andreasi, W. A. (2015b). Effect of wall construction materials over indoor air quality in humid and hot climate. Journal of Building Engineering, 3, 16-23.

Nematchoua, M. K., Tchinda, R., Roshan, Gh. R., Ricciardi, P., \& Nasrabadi, T. (2015a). Climate change and its role on forecasting the energy demand in buildings: Case study of Douala City, Cameroon. Journal of Earth System Science, 124, 269-281.

Nika, V. M., Matab, E., Sasic Kalagasidisc, A., \& Scartezzini, J.-L. (2016). Effective and robust energy retrofitting measures for future climaticconditions-Reduced heating demand of Swedish households. Energy and Buildings, 121, 176-187.

Olonscheck, M., Holsten, A., \& Kropp, J. P. (2011). Heating and cooling energy demand and related emissions of the German residential building stock under climate change. Energy Policy, 39, 4795-4806.

Oropeza-Perez, I., \& Østergaard, P. A. (2014). Energy saving potential of utilizing natural ventilation under warm conditions-A case study of Mexico. Applied Energy, 130, 20-32.

Pilli-Sihvola, K., Aatola, P., Ollikainen, M., \& Tuomenvirta, H. (2010). Climate change and electricity consumption e witnessing increasing or decreasing use and costs? Energy Policy, 38, 2409-2419.

Radhi, H. (2009). Evaluating the potential impact of global warming on the UAE residential buildings-A contribution to reduce the $\mathrm{CO}_{2}$ emissions. Building and Environment, 44, 2451-2462.

Remund, J., Müller, S., Kunz, S., Huguenin-Landl, B., Studer, C., \& Cattin, R. (2017). Global Meteorological Database, Version 7 Software and Data for Engineers Planers and Education. METEOTEST Fabrikstrasse 14 CH-3012 Bern Switzerland, 1-17 www. meteotest.com, www.meteonorm.com.

Rosenthal, D. H., Gruenspecht, H. K., \& Moran, E. A. (1995). Effects of global warming on energy use for space heating and cooling in the United States. The Energy Journal, 16, 77-96.

Sainson Cyclonique 2017. Sainson Cyclonique 2017-2018: La liste des noms dévoilés. http://www.newsmada.com/2017/09/23/saison-cyclonique-2017-2018-la-liste-desnoms-devoilee/.

Srihari Vikram, T., \& Reddy, K. S. (2014). Estimation of heat losses from modified cavity mono-tube boiler receiver of solar parabolic dish for steam generation. Energy Procedia, 57, 371-380.

Stefanovic, V. P., Pavlovic, S. R., Bellos, E., \& Tzivanidis, C. (2018). A detailed parametric analysis of a solar dish collector. Sustainable Energy Technologies and Assessments, 25, 99-110.

Waddicor, D., Fuentes, E., Siso, L., Salom, J., Favre, B., Jimenez, C., \& Azar, M. (2016), Climate change and building ageing impact on building energy performance and mitigation measures application: a case study in Turin, northern Italy. Buildings and Environment, 102, 13-25.

Wan, K., Li, D., Pan, W., \& Lam, J. (2012). Impact of climate change on building energy use in different climate zones and mitigation and adaptation implications. Applied Energy, 97, 274-282.

Wang, H., \& Chen, Q. (2014). Impact of climate change heating and cooling energy use in buildings in the United States. Energy and Buildings, 82, 428-436.

Wang, X., Chen, D., \& Ren, Z. (2010). Assessment of climate change impact on residential building heating and cooling energy requirement in Australia. Buildings and Environment, 45, 1663-1682.

Wati, E., Meukam, P., Nematchoua, M. K., \& Rene, T. (2015). Influence of external shading on optimum insulation thickness of building walls in a tropical region. Applied Thermal Engineering, 90, 754-762. 